\title{
Love thy neighbour? Exploring prejudice against ethnic minority groups in a divided society: the case of Northern Ireland
}

\begin{abstract}
Northern Ireland has seen a rise in racially motivated crimes and incidents reported to police in recent years and, although this has been accompanied by intensified media coverage, this phenomenon has been the subject of relatively little research. The purpose of this study is to evaluate empirically three theories that have been proposed to explain prejudice towards ethnic minorities in Northern Ireland; economic self- interest, social contact, and 'sectarianism as racism'. Using the 2013 Northern Ireland Life and Times Survey, which contains new questions on contact with ethnic minorities, this study looks at attitudes towards Eastern Europeans, Muslims and a third category of 'other ethnic groups'. Results from multivariate linear regression provide evidence for all three theories but also show that the strength and significance of predictive variables for prejudice vary across the minority groups. The findings that there are different motivations for prejudice towards different groups can inform policies to tackle racism in Northern Ireland.
\end{abstract}

\section{Introduction}

Northern Ireland has traditionally been perceived in terms of the binary division between Protestants and Roman Catholics, who comprise $48 \%$ and $45 \%$ of the population, respectively.1 This divide has defined many aspects of lives Northern Irish residents, including which school they send their children to, where they live and who they marry (Nic Craith 2002; McVeigh and Rolston 2007). Over recent decades, however, this division has become less salient as sectarian violence has subsided. Yet, since the 1990s, racially motivated crimes and racism directed against people from ethnic minorities have increased (McVeigh and Rolston 2007; Wallace, McAreavey, and Atkin 2013). This is apparent in the growing volume of media accounts of attacks against ethnic and religious minorities, ranging from routine harassment to extreme acts of violence, with Northern Ireland now described as the 'race hate capital of Europe' (NICEM 2013, 1). However, there has been relatively little quantitative research on racial prejudice among the majority white Irish community. This is unfortunate as, beyond the need for such research to inform policy, Northern Ireland is of interest because it has only experienced significant immigration relatively recently and because much of the migration has been from the post-2004 European Union (EU) member states in Central and Eastern Europe.

This paper begins by reviewing experiences of and responses to racism in Northern Ireland. Then it describes key characteristics of the ethnic minority population in Northern Ireland, reviews existing literature on attitudes to ethnic minorities there and the theories that have been proposed to explain prejudice, and then analyses the determinants of racial prejudice among the non-ethnic minority population using recent survey data.

\section{Racism and the response in Northern Ireland}

Northern Ireland has, until relatively recently, been ethnically homogenous. Geographical isolation and lack of employment opportunities excluded it from the postwar Commonwealth migration to Great Britain. Other than the small, long-established 
Jewish community, most migrants were Hong Kong Chinese, with a few doctors from the Indian sub-continent (Russell 2012, 89). The promise of peace after the Good Friday Agreement created better working conditions and this, coupled with EU expansion, brought a new wave of economic migrants into the region. Many were from Eastern Europe and initially they settled mainly in deprived, predominantly loyalist areas of Northern Ireland (McVeigh and Rolston 2007).

Northern Ireland's still limited experience of immigration is reflected in its weak political response. The Race Relations Order was enacted only in 1997, 21 years after equivalent legislation in Great Britain and, although modelled on it, is perceived to be weaker and less strongly enforced (Northern Ireland Council for Ethnic Minorities) (McCaffery 2013). The Northern Ireland Assembly and Executive have shown little interest; a search for written questions containing the index term 'race relations' in the Hansard record for the Northern Ireland Assembly found only 109 written questions since its establishment in 1998 (accessed 12 October 2014).

Although only a partial reflection of racist behaviour, statistics from the Police Service of Northern Ireland (2014) show increasing reports of racially motivated incidents and crimes, reversing a sustained fall in the decade to 2010 (Figure 1). The number of racist incidents reported in 2013/ 2014 was 30.9\% higher than in the previous year, while reported sectarian incidents had fallen by $6.4 \%$ in the same period. These racially motivated incidents were predominantly concentrated in the capital, Belfast; similar trends are seen for those racially motivated incidents meeting the criteria to be considered criminal.

\section{The ethnic minority population in Northern Ireland}

Estimating the size of the ethnic minority population is complex, requiring triangulation of data from several sources. The census reports self-reported ethnicity and country of

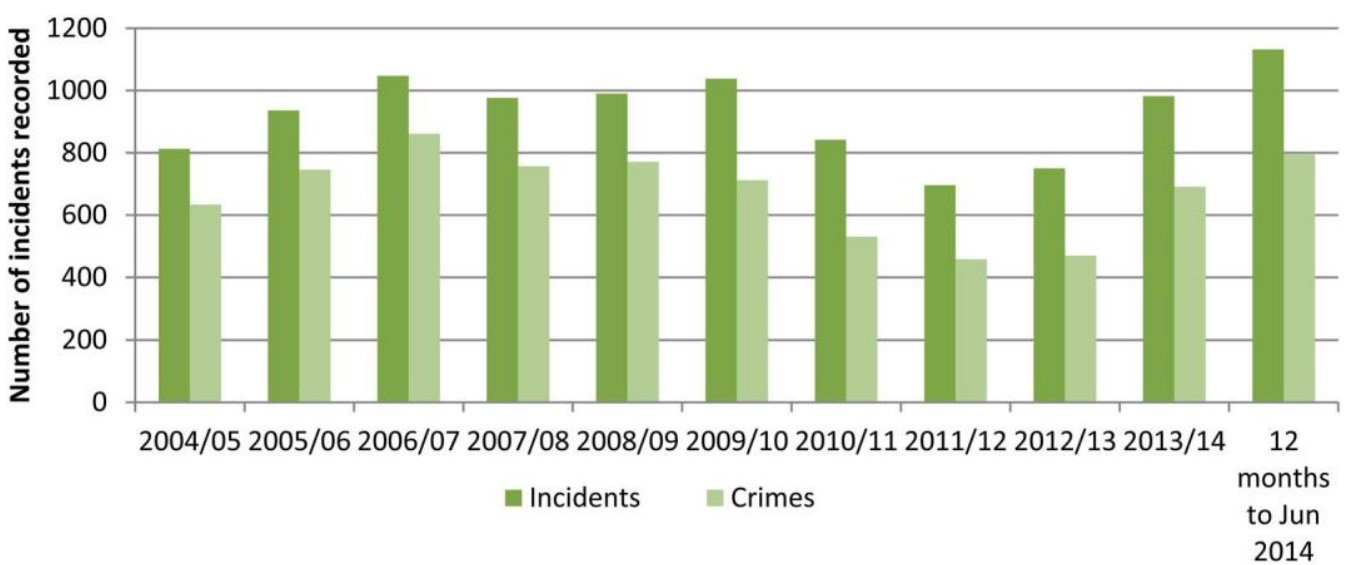

Figure 1. Trends in racist motivated incidents and crimes.

Source: PSNI annual crime statistics, http://www.psni.police.uk/quarterly_hate_motivations_bulletin_apr-jun_14_15.pdf.

birth. The first misses growing numbers of Eastern Europeans, categorised as white. The second excludes people who self- identify as ethnic minorities but are second- or thirdgeneration migrants.

Using the question on self-reported ethnicity in the 2011 Northern Ireland Census (NISRA (Northern Ireland Statistics and Research Agency)) residents belonging to an ethnic 
minority group amounted to 32,400 or $1.8 \%$ of the overall population. This more than doubled since the

2001 Census (0.8\%) although the rise was less than some predicted (Gallagher 2007). During this period, Northern Ireland's population grew by $7.5 \%$, with ethnic minorities accounting for about a sixth of this increase. The three main groups within the ethnic minority population were; Chinese, Indian, Other Asian (Figure 2).

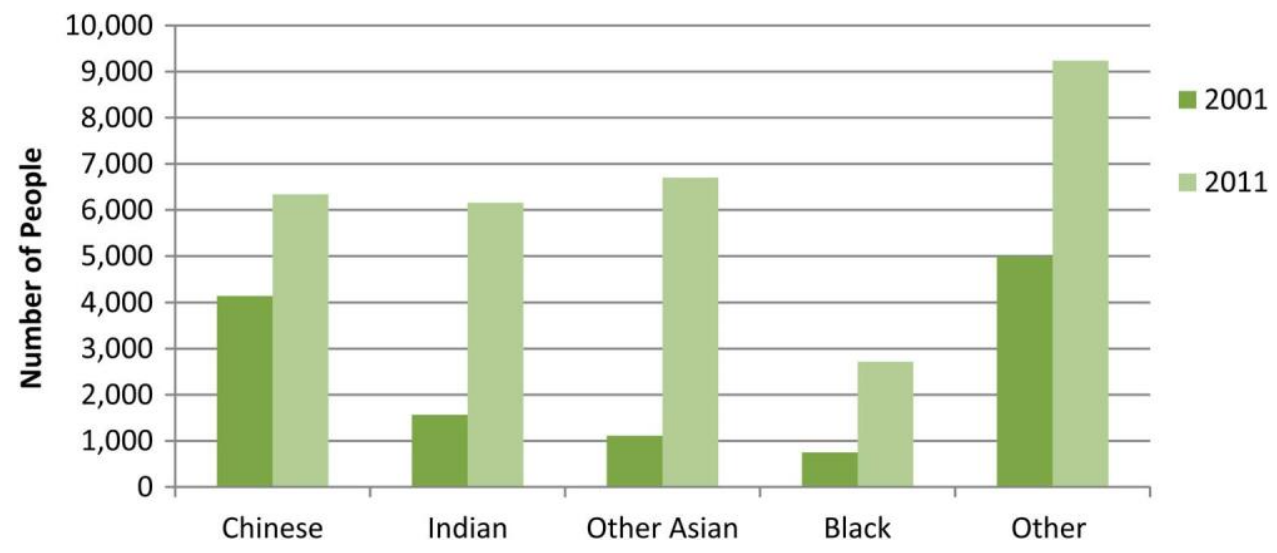

Figure 2. Frequency of main (non-white) ethnic minority groups in Northern Ireland.

Source: Northern Ireland Census 2001/2011. Note: Other Asian = Pakistani, Bangladeshi, Other Asian; Other= Mixed and Other.

As noted above, this question does not capture the rapidly growing population from the 10 Eastern European countries that have joined the EU since 2004, the first eight of which are known as the A8 countries. The large gap in living standards between the A8 and the 15 pre-2004 EU member states made it inevitable that they would be a major source of migrant workers within the EU. Their numbers can be ascertained from the census question on country of birth. However, it is necessary to use both questions to obtain a comprehensive picture.

Figure 3 reveals that just over 33,000 usual residents of Northern Ireland were born in one of the $\mathrm{A} 8$ countries or Bulgaria and Romania, just behind those born in the Republic of Ireland.

The Northern Ireland Life and Times (NILT) survey, used in this paper asks questions about three ethnic/ religious groups; Eastern Europeans, Muslims, and Other. In the Census those who self- identified as Muslim numbered just over 3800 making this group just over one tenth the size of the Eastern European population. ${ }^{2}$ The 'other' ethnic group, while not explicitly defined in the survey, can be assumed to comprise mainly Chinese and Indians (based on census data). 


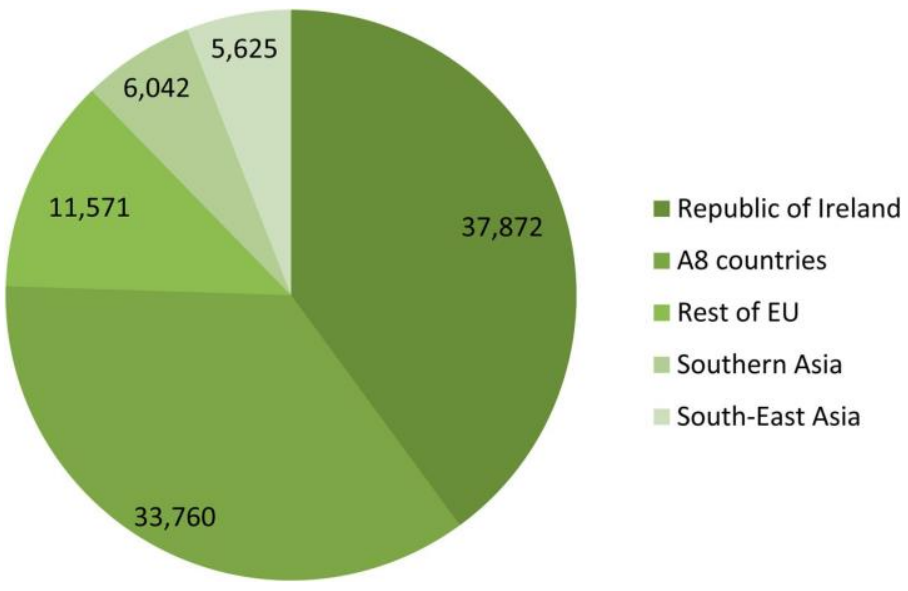

Figure 3. Country of birth excluding Northern Ireland for all usual residents in 2011

Census. Source: NISRA Census 2011.

\section{Previous research on racism in Northern Ireland}

The promise of peace in Northern Ireland following the Good Friday Agreement prompted many studies of the changing relationships between Protestants and Catholics (Cox, Guelke, and Stephen 2000; Paolini et al. 2004; Hewstone et al. 2006). Considerably less attention has been paid to changes in relationships between other growing, but still minority communities in Northern Ireland and the increasing evidence of prejudice against them. Given the previously small numbers of ethnic minorities, it was perhaps understandable that they attracted little attention from researchers. As McVeigh $(1998 b, 11)$ noted, people may perceive that 'racism is not really a problem here because there are no black people here'. However, as growing numbers of people from an ethnic minority background are being born and migrating into Northern Ireland, this issue can no longer be ignored. Much of the evidence on racial prejudice and discrimination in Northern Ireland is found in grey literature, such as reports from official and non-governmental agencies (Jarman and Monaghan 2003; Russell 2012; NICEM 2013), news media (McDonald 2009; BBC News 2013) and online blogs (McCaffery 2013). This provides factual information and context, but not a detailed analysis. Gilligan $(2008,1)$ sums up the state of ethnic and racial studies literature on Northern Ireland stating 'It is either ignored or it is quarantined,' making the observation that some of the most important works almost completely ignore Northern Ireland. McVeigh takes a similar view, arguing that until now the specificity of Northern Irish racism has led researchers to avoid the region. These factors, coupled with the dominance of the discourse on sectarianism, have created a 'mental hurdle' (Smith 1996, 94) to study Northern Ireland.

There are, however, some exceptions. Hainsworth's (1998) book Divided Society: Ethnic Minorities and Racism in Northern Ireland, provides a rich account of experiences of ethnic minorities in Northern Ireland, with specific chapters on Jewish, Pakistani, and Indian communities. Furthermore several empirical studies use data from Northern Ireland (McVeigh 1992; Hayes and Dowds 2006; McVeigh and Rolston 2007; Knox 2010; Pehrson, Gheorghiu, and Ireland 2012). Thus, there is no reason why Northern Ireland should be quarantined and, in fact, the growing number of ethnic minorities, coupled with new and improved data and increased media coverage of racial attacks allow us to 
address this issue. In the following section I draw on this earlier work toidentify different theories that have been proposed to explain racism and assess their explanatory power in the context of Northern Ireland.

\section{Sectarianism as racism}

Previous literature on Northern Ireland society has focused on sectarianism and specific relationships between Protestants and Catholics. However, several authors have argued that sectarianism in Northern Ireland is not as unique as it is made out to be and is, in fact, an extension of racism, here termed the 'sectarianism as racism' theory (Brewer 1992; McVeigh 1998a; McVeigh and Rolston 2007; Finlay 2010). Robert McVeigh, one of the most prolific writers on racism in Northern Ireland, provides a much needed critique of the dominance of sectarianism in the literature, which he considers has led to discussion of racism being sidelined (McVeigh 1992, 1998a, 1998b; McVeigh and Rolston 2007). McVeigh argues that Northern Ireland is seen as distinct and unique within the global literature on racism because of the perceived specificity of sectarianism and goes on to argue, as Brewer (1992) did, that sectarianism is a form of racism and the religious element has only created unnecessary confusion. Thus, certain characteristics, based on religious stereotyping, are attributed rigidly to one part of the population, setting them apart from the other. Focusing on sectarianism as unique is unhelpful as it either ignores or isolates the problem when in fact 'people are perfectly capable of being both sectarian and racist' (McVeigh and Rolston 2007, 13).

To test whether racism will correlate with sectarianism it is necessary to find a way of capturing sectarianism. This is not straightforward and some imaginative methods have been used, although few are appropriate for use in surveys. In surveys it has often been measured using the question of whether someone from the Protestant or Catholic faith is opposed to having someone marry into their family from the 'other' religion (Knox 2010). Knox's (2010) study using the NILT data found that responses to this question were a significant predictor of racial prejudice, viewed as lending support to the theory of a link between sectarianism and racism.

What is less clear is whether these observed associations are due to sectarianism per se or religion. McVeigh and Rolston note selective migration of ethnic minorities to more crowded 'loyalist' working-class areas, characterised not only by being predominantly Protestant but also by prevalent sectarian attitudes. This has given rise to a perceived link between loyalism and racism that is implicitly or explicitly described in media reports. Consistent with this view, several studies have found religion to be a determinant of prejudice in Northern Ireland (Connolly and Keenan 2000; Gilligan 2008). Knox's (2010) paper, examining racism in Northern Ireland, finds that Protestants are more likely than Catholics to present prejudiced attitudes while Pehrson, Gheorghiu, and Ireland (2012) found that Protestants were more prejudiced in relation to all three minority groups they looked at, while the biggest difference was in their attitudes towards Muslims. Thus, there is evidence to link both religion and sectarian values to prejudice against minority groups.

It is, however, also important to consider whether Protestants and Catholics have different degrees of contact with other minorities. The role of social contact is discussed in a later section but for now it can be noted that the NILT data show that Catholics do have significantly more contact with Eastern Europeans (Figure 4), presumably because many of the latter are Catholic ${ }^{3}$ but there is no significant difference in the degree of contact that Protestants and Catholics have with Muslims ${ }^{4}$ or other ethnic groups. ${ }^{5}$

For these reasons, research on racial prejudice in Northern Ireland should look 
separately at religious identification and sectarian attitudes.

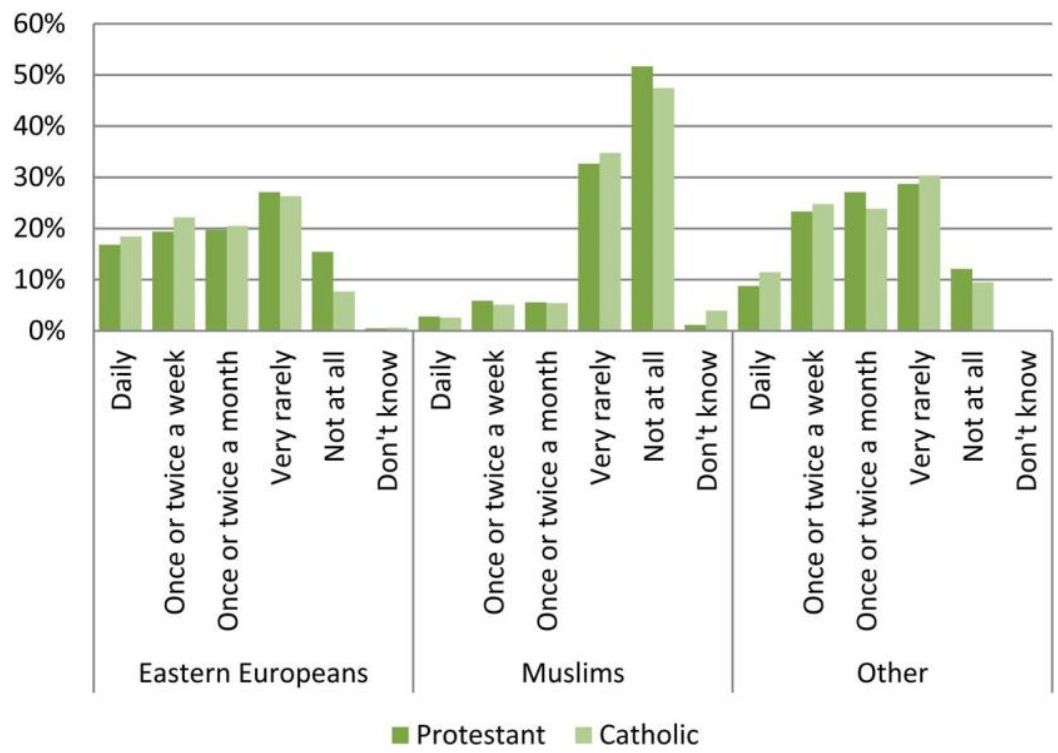

Figure 4. Reported contact with ethnic minorities by native Protestants and Catholics.

\section{Economic self-interest}

Economic self-interest theory is based on the idea that minorities, especially migrants, pose an economic threat to the existing, majority ethnic group. Taking its cue from group threat theory (Quillian 1995), some have linked the rise of prejudice in settings where minority groups are especially numerous to competition for jobs and scarce resources, narrowing the concept to 'economic threat' (Blumer 1958; Blalock 1967; Bonacich 1972; Bobo 1983). Thus, prejudice can be an outcome of a threat from the minority group, for reasons such as their ability to provide cheaper labour and undercut the higher wages of the established majority, known as 'realistic threats' (Blalock 1967) as opposed to symbolic or perceived threats such as conflicts with language and culture. Realistic group threat theory helps to explain how competition for these scarce and tangible resources can lead to a perception that the interests of the 'in-group' are threatened and thus gives rise to increased prejudice towards the 'out-group'.

According to this theory, the in-group believe that they will be disproportionately affected by increasing numbers of ethnic minorities near their home or in their workplace and are more likely to be prejudiced towards them. It predicts that negative attitudes towards out-groups will be greatest among those strata of the population that hold positions similar to immigrant groups, by virtue of their low social class and education, and who therefore are most vulnerable to competition (Scheepers, Gijsberts, and Coenders 2002). This is also apparent in studies looking at determinants of support for extreme right wing parties or strong opposition to immigration (Golder 2003; Ford and Goodwin 2010).

Different measures of economic status have been used to test economic threat theories, including household income (reported or perceived), social class, and perceptions of the 
economy. Reported income has intuitive strengths, where available, but is a static measure, whereas economic threat may be more closely related to changes in income over time, either recalled from the past or anticipated for the future. Hence, perceived financial situation may be a better measure in this context.

Although education is not, in itself, a measure of economic threat, many studies have shown that low education renders individuals vulnerable to perceived economic threat from migrants who may be competing for the same scarce resources, including employment (Kluegel and Smith 1983; Citrin et al. 1997), but have the same or higher levels of education. This mechanism is borne out by evi- dence that skilled workers are more accepting of migrants in those settings where migrants are less skilled, and less so where they are more skilled (Mayda 2006). The effect does seem, however, to be somewhat greater among labour market participants, as might be expected (O'Rourke and Sinnott 2006) while the evidence is conflicting as to whether the effect is different in areas with high and low immigration levels (Scheve and Slaughter 2001). In contrast, better educated individuals have greater reserves of human capital and thus are more resilient to, and less threatened economically by minority groups (van Oorschot 2000; Raijman, Semyonov, and Schmidt 2003) and, empirically, have been shown to be more tolerant (Hagendoorn and Nekuee 1999); Thus, although not strictly an economic variable, from a theoretical perspective education can be considered an appropriate indicator of vulnerability to economic threat. As a result, education is frequently included in empirical research into racial prejudice.

Empirically, while it is correlated with income, it is a distinct measure as a number of studies find that education can explain differences in racial prejudice independent of income (Case, Greely, and Fuchs 1989; Wagner and Zick 1995; Carvacho et al. 2013). In a review of studies of the role of income, education, employment, and occupational class, van Oorschot and Uunk $(2007,65)$ conclude that 'education proves to have the most consistent and strongest effect'. In summary, economic self-interest theory predicts that those, whose economic situation is most precarious, such as those who have less education, are unemployed, and with lower incomes would report more prejudiced attitudes towards minority groups.

\section{Social contact}

The theory that contact among people with different characteristics will reduce prejudice has long underpinned policies to improve relations between communities, including integrated residential development and schools. Allport's (1954) research published in 'The Nature of Prejudice' is the most influential. He suggests that contact between a minority and majority group can weaken prejudice and stereotypes in specific situational conditions (Pettigrew 1998). According to this, contact with members of ethnic minorities under these conditions is predicted to positively affect attitudes towards members of those groups. These conditions have been taken to mean slightly different things by researchers; some have argued that knowing someone from another group who lives in your community is sufficient to confer equal status, as those living in the same neighbourhood tend to have similar social status (Dixon and Rosenbaum 2004). Importantly, there is some evidence that when the conditions are not met there may be negative consequences for relations between minorityand majoritygroups(Brooks 1975). However, most of the recentevidence finds positive effects even if the key conditions are not wholly met (Pettigrew 1998). This observation has led Pettigrew to decry some current research in which writers are becoming bogged down with the theories, confusing 'facilitating with essential conditions'. Pettigrew and Tropp (2006), in a meta-analysis of evidence for intergroup contact theory, concluded that contact, under Allport's conditions, is more effective in 
reducing prejudice, but contact without these conditions also works. This provides scope for researchers to analyse contact even when the data do not provide information on these conditions. Hayes and Dowds (2006) conducted an extensive analysis of attitudes towards immigrants in Northern Ireland. They tested three alternative theories which purport to explain attitudes towards minorities; social contact, cultural marginality, and economic self-interest. Using the Northern Ireland component of the European Social Survey, from 2003, they found that social exposure and cultural marginality were both independently able to predict pro-immigration attitudes, with prior social contact among the most significant drivers. Thus, we might predict that social contact with members of ethnic minorities groups would have a positive effect on the respondent's attitudes towards members of the same groups.

These theories, which draw on previous research, underpin the analyses in this study. However, as noted above much of the research has concentrated rather one dimensionally on the experience of and attitudes towards minorities in general or has examined individual theories. There is a need for further research that recognises the diversity of ethnic minorities and the prejudice towards them. For example, some explanations for prejudiced attitudes towards Muslims may be different from those explaining attitudes towards Eastern Europeans who, because they are white and predominantly Catholic, might find it easier to fit into certain communities. Of the over $33,000^{6}$ individuals living in Northern Ireland and born in Eastern European (post-2004 accession), $75 \%^{7}$ describe themselves as Roman Catholic. This highlights the need for theories of prejudice to be tested among a range of ethnic and religious minorities, in order to recognise the diverse processes by which prejudice arises against different groups and thus to inform policies that might address them. Thus, the aim of this study is to obtain insights into prejudice towards different minority groups using pre- existing theories. The study does not seek to compare formally their explanatory power, given the need to work with available variables, some of which are proxies for the different theories rather than direct measures of the relevant constructs such as sectarianism or perceived economic threat although, in these cases, this is an inevitable limitation given the absence of validated survey measures and the scope for problems such as social desirability bias.

\section{Measuring prejudice}

In order to analyse prejudice it is necessary to first decide on exactly what we are looking at. Allport defined prejudice as 'an antipathy based upon a faulty and inflexible generalization' (Allport 1954, 10). A simpler and widely accepted definition is that prejudice is a negative attitude towards a particular social group or person belonging to it (Augoustinos and Reynolds 2001, 2; Dovido et al. 2010, 45-46). In this sense, prejudice is defined as one or more unjustified and rigid negative attitudes projected upon a group of people sharing similar characteristics.

With a clear definition of prejudice, we look to the extensive literature on prejudice in survey research to see how we can measure this phenomenon. However, possibly because it is so extensive, the literature contains many, sometimes muddled ways of measuring this. These are often tied to concepts of 'stereotypes' and 'discrimination', elements of which share similarities but the definitions used, and their operationalisation, vary.

Since the early survey research on prejudice (Katz and Braly 1933), respondents have been asked directly about their attitudes or their perceived prejudices. This direct measure of prejudice is now widespread, often in the form 'are you prejudiced?'. 
However, this approach has been criticised because of arguably obvious limitations in that it can only provide a valid estimate of the respondent's level of prejudice if they are willing and able to report it. This can easily be subject to social desirability bias, given that it is now deemed unacceptable in many cultures to overtly express prejudice towards certain groups in society, although to differing degrees (Schuman, Steeh, and Lawrence 1997). Additionally, it relies on respondents having the same view of what constitutes prejudice and being able to recognise whether their own attitudes are prejudiced. Finally, this question does not indicate which ethnic or religious groups the respondents are prejudiced against. Given the many assumptions required to interpret direct questions on prejudice, responses may be invalid and unreliable and, in particular, may underestimate its extent.

A measure based on the Bogardus Social Distance Scale has been used in more recent studies. The respondent is not asked directly if they are prejudiced; instead their level of prejudice is calculated from their willingness to engage with someone of a different group, thus not relying on the respondent's introspective analysis of their attitudes. Knox (2010) uses the social distance scale but dichotomises the scale of six variables into not prejudiced (would accept a minority member into the family) and prejudiced (all other categories) to use it in a binary logistic regression. Pehrson, Gheorghiu, and Ireland (2012) conducted a more in depth analysis, also using the social distance scale from the NILT data. They undertook structural equation modelling and path analysis to identify latent factors, to explore differences in racial attitudes from the perspective of Protestants and Catholics. This analysis also made use of the fact that the question is asked about three different ethnic groups. For the purpose of this study we employ the Social Distance Scale to measure prejudice, the details of which are explained in the next section.

\section{Data and methods}

This study uses the 2013 NILT Survey. The aim of the survey is to 'monitor the attitudes and behaviour of people in Northern Ireland annually to provide a time series and public record of how our attitudes and behaviour develop on a wide range of policy issues' (ARK 2010, 1). The 2013 data comprise 1210 face-to-face interviews with adults aged 18 or over and included both an interview and a self-completion questionnaire. The 2013 survey includes a section on attitudes to minority ethnic people and migrant workers. Some of the questions were changed after the 2012 survey, including those on contact with ethnic minorities, which are now aligned with the social distance questions. The data are weighted for household size. For the purpose of this study only respondents who declared themselves not to be from an ethnic minority background were included in the analysis. The statistical analysis was performed using Stata version 14.

\section{Dependent variable}

In this study the dependent variable, prejudice, is measured using the social distance scale. The scale measures each respondent's willingness to engage socially with people from a group. It is derived from a set of questions on whether the respondent would accept someone from each group at different levels of social distance from them, thus revealing how accepting they are of each group. Additionally the scale is cumulative (meeting the criteria of a Guttman scale) so that if the respondent accepts someone at one level they will accept them at all previous levels. The social distance scale has been computed so that those who said no at every question (within each group) scored 1 (least accepting) and respondents who stated yes to every question, accepted someone at every level scored 7 (most accepting). Thus (scores in parentheses), if someone 
accepts an Eastern European as a relative by marriage (7) they would also accept them as, in increasing order of social distance, a close friend (6), a colleague at work (5), a resident in their local area (4), a resident of Northern Ireland (3), and a tourist visiting Northern Ireland (2), while those rejecting them in all of these categories scores 1. Scales were computed for all three groups. Although there are some obvious problems with the vagueness of the 'other' category, this is used primarily as a reference point for the other two groups rather than having merit in and of itself.

Preliminary analysis of the data (see supplementary material) confirmed that the scales used in this study, each relating to an ethnic group, conform to the criteria for a Guttman Scale. Each of the scales also shows excellent reliability, with Cronbach's alpha values as follows: Eastern European 0.901; Muslim 0.913; and Other 0.847. This scale, as Knox $(2010,403)$ explains, is useful in its simplicity, so that it provides a 'onedimensional assessment of racial attitudes'. Moreover while the nature of these relationships, for example, as a tourist, or as a family member are different, it has proven an effective measure for analysing prejudice, especially compared with more direct measures. Comparing data from the 2013 NILT survey with those from earlier waves (Table 1) shows how attitudes towards ethnic minorities have changed between 2010 and 2013. The scores on the social distance scale show that, for all three groups, respondents are increasingly less likely to accept them at all levels. Thus, it would appear that prejudice towards all three groups is increasing. As a reminder, acceptance as a relative by marriage indicates the least prejudiced that a respondent can be.

Table 1 indicates that attitudes towards Muslims are the most negative; only $40 \%$ of people would accept them as a relative through marriage, while the largest change in attitudes has been in relation to the 'other' ethnic group, followed by Eastern Europeans. Views of Muslims have changed little in the last three years, whereas changes in attitudes towards the other two groups have been more marked. The table also reveals that respondents are more accepting of ethnic minorities when they are at a further social distance. This holds for all three groups although the difference is greatest for Muslims, with a $40 \%$ fall between accepting them as a tourist and accepting them as a relative. This provides support for the premise underpinning this paper, that attitudes towards ethnic minorities are not homogenous. Levels, patterns, and trends in prejudice vary and so it is likely that the determinants of prejudice will also vary.

Table 1. Changing willingness to accept different groups in Northern Ireland in 2010 and $2013(n)$.

\begin{tabular}{|c|c|c|c|c|c|c|c|}
\hline & & Tourist & Resident of NI & Resident of local area & Colleague & Close friend & Relative \\
\hline \multirow[t]{3}{*}{ Eastern European } & 2010 & $\begin{array}{l}98 \% \\
(1089)\end{array}$ & $\begin{array}{l}83 \% \\
(923)\end{array}$ & $\begin{array}{l}83 \% \\
(921)\end{array}$ & $\begin{array}{l}88 \% \\
(975)\end{array}$ & $\begin{array}{l}77 \% \\
(858)\end{array}$ & $\begin{array}{l}76 \% \\
(842)\end{array}$ \\
\hline & 2013 & $\begin{array}{l}88 \% \\
(1000)\end{array}$ & $\begin{array}{l}79 \% \\
(892)\end{array}$ & $\begin{array}{l}73 \% \\
(825)\end{array}$ & $\begin{array}{l}69 \% \\
(788)\end{array}$ & $\begin{array}{l}57 \% \\
(651)\end{array}$ & $\begin{array}{l}53 \% \\
(600)\end{array}$ \\
\hline & $\%$ change & $-9 \%$ & $-4 \%$ & $-10 \%$ & $-18 \%$ & $-20 \%$ & $-23 \%$ \\
\hline \multirow[t]{3}{*}{ Muslim } & 2010 & $\begin{array}{l}87 \% \\
(982)\end{array}$ & $\begin{array}{l}72 \% \\
(822)\end{array}$ & $\begin{array}{l}68 \% \\
(776)\end{array}$ & $\begin{array}{l}72 \% \\
(821)\end{array}$ & $\begin{array}{l}61 \% \\
(694)\end{array}$ & $\begin{array}{l}51 \% \\
(583)\end{array}$ \\
\hline & 2013 & $\begin{array}{l}80 \% \\
(913)\end{array}$ & $\begin{array}{l}70 \% \\
(795)\end{array}$ & $\begin{array}{l}63 \% \\
(715)\end{array}$ & $\begin{array}{l}60 \% \\
(683)\end{array}$ & $\begin{array}{l}50 \% \\
(566)\end{array}$ & $\begin{array}{l}40 \% \\
(458)\end{array}$ \\
\hline & $\%$ change & $-7 \%$ & $-3 \%$ & $-6 \%$ & $-13 \%$ & $-12 \%$ & $-11 \%$ \\
\hline \multirow[t]{3}{*}{ Other ethnic group } & 2010 & $\begin{array}{l}99 \% \\
(1123)\end{array}$ & $\begin{array}{l}92 \% \\
(1046)\end{array}$ & $\begin{array}{l}90 \% \\
(1029)\end{array}$ & $\begin{array}{l}91 \% \\
(1034)\end{array}$ & $\begin{array}{l}83 \% \\
(947)\end{array}$ & $\begin{array}{l}79 \% \\
(894)\end{array}$ \\
\hline & 2013 & $\begin{array}{l}89 \% \\
(1027)\end{array}$ & $\begin{array}{l}85 \% \\
(977)\end{array}$ & $\begin{array}{l}80 \% \\
(915)\end{array}$ & $\begin{array}{l}73 \% \\
(835)\end{array}$ & $\begin{array}{l}59 \% \\
(683)\end{array}$ & $\begin{array}{l}54 \% \\
(625)\end{array}$ \\
\hline & $\%$ change & $-10 \%$ & $-7 \%$ & $-11 \%$ & $-18 \%$ & $-24 \%$ & $-25 \%$ \\
\hline
\end{tabular}




\section{Independent variables}

Age and gender are included in the models as controls. Respondents are relatively equally divided by gender, with males making up $46 \%$ and females $54 \%$ of the sample, reflecting the Census data. The remaining independent variables have been chosen to be as consistent as possible with Hayes and Dowds' (2006) and Knox's (2010) research to allow for continuity in the literature and comparisons with newer data while taking account of improvements to the survey questions. The two blocks of independent variables from Hayes and Dowds' (2006); social contact hypothesis and economic self- interest theory are both included and variables for the theory of McVeigh and others (Brewer 1992; McVeigh 1998a; McVeigh and Rolston 2007) positing a link between sectarianism and racism have been included.

The social contact hypothesis is tested using a measure of the level of contact the respondent has with people from each of the three groups. The question asks 'How often do you have contact with Eastern Europeans/Muslims/Other ethnic group?'. This set of questions makes it possible to study the effect of contact with each ethnic group directly. Among the three groups, respondents state that they have the most contact with Eastern Europeans, with $18.6 \%$ stating they have daily contact and $10.9 \%$ stating they have never had contact (Table 2 ). $48.7 \%$ of respondents report that they had never had contact with a Muslim and only $3.2 \%$ have daily contact. $10 \%$ report never having contact with someone from the other ethnic group, while $11 \%$ report that they have daily contact.

Table 2. Frequency of contact with ethnic groups NILT2013.

\begin{tabular}{|c|c|c|c|c|c|}
\hline \multirow[b]{2}{*}{ Ethnic group } & \multicolumn{5}{|c|}{ Contact } \\
\hline & Never & Very rarely & 1-2 times per month & 1-2 times per week & Daily \\
\hline Eastern Europeans & $\begin{array}{c}10.9 \% \\
(123)\end{array}$ & $\begin{array}{c}26.8 \% \\
(301)\end{array}$ & $\begin{array}{c}21.3 \% \\
(240)\end{array}$ & $\begin{array}{c}22.4 \% \\
(251)\end{array}$ & $\begin{array}{r}18.6 \% \\
(208)\end{array}$ \\
\hline Muslims & $\begin{array}{c}48.7 \% \\
(540)\end{array}$ & $\begin{array}{c}35.3 \% \\
(391)\end{array}$ & $\begin{array}{r}6.7 \% \\
(75)\end{array}$ & $\begin{array}{c}6.1 \% \\
(67)\end{array}$ & $\begin{array}{r}3.2 \% \\
(36)\end{array}$ \\
\hline Other ethnic group & $\begin{array}{c}10.0 \% \\
(114)\end{array}$ & $\begin{array}{c}27.6 \% \\
(315)\end{array}$ & $\begin{array}{c}26.1 \% \\
(299)\end{array}$ & $\begin{array}{c}25.4 \% \\
(290)\end{array}$ & $\begin{array}{r}11 \% \\
(125)\end{array}$ \\
\hline
\end{tabular}

Note: $n$ is in parentheses.

The second hypothesis, linking sectarianism and racism, is tested by asking whether individuals are in favour of more religious mixing in marriages, taking into account their respondent's religion (Catholic or Protestant). This is asked as part of a selection of questions on sectarian attitudes. As noted above, the respondent's opposition to marriages between Catholics and Protestants, when traditionally mixed marriages have not been the norm, is considered an indicator of religious prejudice, and thus sectarianism.

Economic self-interest is operationalised using three variables; social class, education, and subjective household income. Social class is measured by Goldthorpe's $(1987,39-$ 42) social class schema using 3 occupational classes $^{8}$ (Social Class (SC) 1 Higher managerial, administrative, and professional occupations; SC2 Intermediate occupations; SC3 Routine and Manual occupations; reference category never worked and long-term unemployed, hereafter referred to as SC4). The majority of respondents are employed in the routine and manual occupations (38.8\%), while those working in the higher managerial, administrative, and professional occupations and intermediate occupations make up $28.4 \%$ and $24.4 \%$ of the sample, respectively, only $8.4 \%$ of respondents have never worked or are long-term unemployed. Education has been recoded into three variables (Higher education, degree or higher; A levels, GCSEs or 
equivalent; reference category no qualification). Household income is measured using the respondent's subjective view of their household earnings over the last year and whether or not it has fallen or exceeded/ kept up with prices. Measures of how financially secure or not a person feels is more likely to affect their attitudes to economic threats than their real household income.

The characteristics of the sample are shown in Table 3 below; this includes the frequency of respondents for each variable used in the analysis.

Table 3. Characteristics of the sample from the NILT 2013.

\begin{tabular}{|c|c|c|}
\hline Block & $\begin{array}{l}\text { Variable } \\
n\end{array}$ & \\
\hline Gender & $\begin{array}{l}\text { Male } \\
\text { Female }\end{array}$ & $\begin{array}{l}532 \\
618\end{array}$ \\
\hline \multicolumn{3}{|l|}{ Social Contact } \\
\hline \multirow[t]{5}{*}{ EasternEuropean } & Not at all & 123 \\
\hline & Very rarely & 301 \\
\hline & $1-2$ times a month & 240 \\
\hline & $1-2$ times a week & 251 \\
\hline & Daily & 208 \\
\hline \multirow[t]{5}{*}{ Muslim } & Not at all & 125 \\
\hline & Very rarely & 391 \\
\hline & 1-2 times a month & 75 \\
\hline & $1-2$ times a week & 67 \\
\hline & Daily & 36 \\
\hline \multirow[t]{5}{*}{ Other } & Not at all & 540 \\
\hline & Very rarely & 114 \\
\hline & $1-2$ times a month & 315 \\
\hline & 1-2 times a week & 299 \\
\hline & Daily & 290 \\
\hline \multirow[t]{5}{*}{ Sectarianism } & Protestant & 463 \\
\hline & Catholic & 488 \\
\hline & No or other religion & 199 \\
\hline & In favour of mixed marriages & 837 \\
\hline & Keep as it is/against more mixing & 255 \\
\hline \multirow[t]{9}{*}{ Economic self-interest } & Never worked/long term unemployed & 114 \\
\hline & Routine/manual & 430 \\
\hline & Intermediate & 282 \\
\hline & Managerial & 305 \\
\hline & No qualifications & 248 \\
\hline & GCSE/A Level & 525 \\
\hline & Degree or higher & 338 \\
\hline & Household income keeping up with prices & 374 \\
\hline & Household income not keeping up with prices & 742 \\
\hline
\end{tabular}

\section{Hypotheses}

Three hypotheses will be tested in this paper, derived directly from three theories described above, and embedded in the existing literature on prejudice. It is hypothesised that the results will differ with respect to the three minority groups. The three hypotheses are as follows:

(1) Those who have more contact with individuals from ethnic minorities will be less prejudiced against them (social contact hypothesis) (Hayes and Dowds 2006);

(2) Those who are less accepting of mixed marriages will be more prejudiced against ethnic minorities (sectarianism as racism), with religion included as a control (Brewer 
1992; McVeigh and Rolston 2007; Knox 2010);

(3) Those whose economic situation is most precarious, such as those who are unemployed, and those who are disappointed in their economic situation will be more prejudiced (economic self-interest) (Hayes and Dowds 2006).

It is important to reiterate that this study cannot directly compare the explanatory power of these three theories, given the use of proxy variables to capture their core elements, but instead seeks to ascertain the extent of prejudice against three minority groups, the extent to which widely used theories can offer insights into the reasons for any prejudice, and how this may vary among the minority groups. The three hypotheses are tested using linear regression, repeated for each of the three ethnic minority groups appearing in the NILT survey, with variables corresponding to each hypothesis being added in blocks following adjustment for socio-demographic factors (Table 4). The table reports constants, unstandardised and standardised coefficients, as well as the significance level for each association and the number of observations. The last of these varies because of differences in non-response among variables, which was especially high for the question on attitude to mixed marriage. To recall, the parameters reported can be used to assess the impact of changes in the variables. Thus, after adjustment for age and sex, someone with no contact with Eastern Europeans will score 4.983 on the Social Distance Scale, equivalent to accepting them as a resident of the local area but not quite as a colleague, whereas someone with daily contact would score $4.983+1.739=6.632$, indicating acceptance as somewhere between a close friend and relative.

A further linear regression was undertaken, including all of the variables from the three blocks (Table 5). A logistic regression was also undertaken (not shown), dichotomising the social distance scale into acceptance into the family and all the rest, as was done by Knox (2010). The directions of associations were the same, although the significance varied. However, the use of the entire scale conveys the full range of circumstances in which there is acceptance of a person from the minority group, thus maximising the information provided. Finally, some sub-analyses were undertaken to explore whether the observed associations were consistent within different groups in the population. 
Table 4. Multiple linear regression results for the social distance scale; Eastern European, Muslim, and Other ethnic group (entered in blocks, each adjusted for gender and age).

\begin{tabular}{|c|c|c|c|c|c|c|c|}
\hline \multirow[b]{2}{*}{ Block } & \multirow[b]{2}{*}{ Variable } & \multicolumn{2}{|c|}{ Eastern European } & \multicolumn{2}{|l|}{ Muslim } & \multicolumn{2}{|l|}{ Other } \\
\hline & & $B$ & Beta & $B$ & Beta & $B$ & Beta \\
\hline \multirow[t]{5}{*}{ Social contact } & Never (reference) & [123] & & [539] & & [114] & \\
\hline & Very rarely & $\begin{array}{c}0.918(.255)^{* * *} \\
{[300]}\end{array}$ & 0.197 & $\begin{array}{c}1.255(.167)^{\star * *} \\
{[389]}\end{array}$ & 0.253 & $\begin{array}{c}0.830(.251)^{\star *} \\
{[315]}\end{array}$ & 0.194 \\
\hline & 1-2 times a month & $\begin{array}{c}0.863(.275)^{\star *} \\
{[238]}\end{array}$ & 0.171 & $\begin{array}{c}1.685(.260)^{* * *} \\
{[74]}\end{array}$ & 0.177 & $\begin{array}{c}0.792(.258)^{* *} \\
{[298]}\end{array}$ & 0.182 \\
\hline & 1-2 times a week & $\begin{array}{c}1.222(.265)^{\star * *} \\
{[251]}\end{array}$ & 0.247 & $\begin{array}{c}1.521(.281)^{\star * *} \\
{[66]}\end{array}$ & 0.153 & $\begin{array}{c}1.186(.258)^{\star \star *} \\
{[290]}\end{array}$ & 0.270 \\
\hline & Daily & $\begin{array}{c}1.739(.260)^{\star * *} \\
{[109]}\end{array}$ & 0.328 & $\begin{array}{c}1.382(.433)^{\star *} \\
{[36]}\end{array}$ & 0.103 & $\begin{array}{c}1.503(.284)^{\star \star *} \\
{[125]}\end{array}$ & 0.246 \\
\hline Constant & & 4.893 & & 5.220 & & 5.162 & \\
\hline & & 1211 & & 1104 & & 1142 & \\
\hline Adjusted $r^{2}$ & & 0.072 & & 0.142 & & 0.063 & \\
\hline Sectarianism & Protestant (reference) & [436] & & [435] & & [454] & \\
\hline Religion & Catholic & $\begin{array}{c}0.692(.148)^{* * *} \\
{[450]}\end{array}$ & 0.170 & $\begin{array}{c}0.904(.168)^{* * *} \\
{[451]}\end{array}$ & 0.193 & $\begin{array}{c}0.591(.136)^{* * *} \\
{[440]}\end{array}$ & 0.157 \\
\hline \multirow[t]{2}{*}{ Mixed Marriages } & Supports (reference) & [657] & & [655] & & [661] & \\
\hline & Opposed & $\begin{array}{c}0.497(.179)^{\star *} \\
{[229]}\end{array}$ & 0.106 & $\begin{array}{c}0.874(.193)^{\star * *} \\
{[231]}\end{array}$ & 0.162 & $\begin{array}{c}0.537(.164)^{\star *} \\
{[233]}\end{array}$ & 0.124 \\
\hline Constant & & 5.472 & & 5.045 & & 5.694 & \\
\hline$N$ & & 886 & & 886 & & 894 & \\
\hline Adjusted $r^{2}$ & & 0.076 & & 0.147 & & 0.083 & \\
\hline \multirow[t]{4}{*}{ Economic self-interest } & $\begin{array}{l}\text { Never worked/long } \\
\text { term unemployed }\end{array}$ & [108] & & [106] & & [108] & \\
\hline & Routine/manual & $\begin{array}{c}1.279(.282)^{\star * *} \\
{[410]}\end{array}$ & 0.302 & $\begin{array}{c}0.796(.291)^{* *} \\
{[413]}\end{array}$ & 0.165 & $\begin{array}{c}1.237(.256)^{\star * *} \\
{[415]}\end{array}$ & 0.316 \\
\hline & Intermediate & $\begin{array}{c}1.293(.301)^{\star * *} \\
{[263]}\end{array}$ & 0.269 & $\begin{array}{c}0.966(.313)^{\star *} \\
{[266]}\end{array}$ & 0.176 & $\begin{array}{c}1.214(.272)^{\star * *} \\
{[268]}\end{array}$ & 0.272 \\
\hline & Managerial & $\begin{array}{c}1.193(.311)^{* * *} \\
{[275]}\end{array}$ & 0.257 & $\begin{array}{c}1.004(.319)^{* *} \\
{[277]}\end{array}$ & 0.190 & $\begin{array}{c}1.185(.280)^{\star * *} \\
{[279]}\end{array}$ & 0.276 \\
\hline \multirow[t]{3}{*}{ Education } & No qualification & [273] & & [276] & & [277] & \\
\hline & GCSE/A Level & $\begin{array}{c}0.644(.203)^{\star *} \\
{[469]}\end{array}$ & 0.155 & $\begin{array}{c}0.569(.229)^{*} \\
{[471]}\end{array}$ & 0.122 & $\begin{array}{c}0.596(.193)^{\star *} \\
{[476]}\end{array}$ & 0.155 \\
\hline & Degree or higher & $\begin{array}{c}1.191(.252)^{* * *} \\
{[314]}\end{array}$ & 0.266 & $\begin{array}{c}1.300(.280)^{* * *} \\
{[315]}\end{array}$ & 0.254 & $\begin{array}{c}1.222(.231)^{\star *} \\
{[317]}\end{array}$ & 0.294 \\
\hline \multirow{2}{*}{$\begin{array}{l}\text { Household income } \\
\text { and prices }\end{array}$} & Fallen behind & [694] & & [699] & & [703] & \\
\hline & Kept up & $\begin{array}{c}-0.288(.137)^{*} \\
{[362]}\end{array}$ & -0.065 & $\begin{array}{c}-0.133(.155) \\
{[363]}\end{array}$ & -0.027 & $\begin{array}{c}-0.146(.121) \\
{[367]}\end{array}$ & -0.036 \\
\hline Constant & & 3.93 & & 4.297 & & 4.185 & \\
\hline$N$ & & 1056 & & 1062 & & 1070 & \\
\hline Adjusted $r^{2}$ & & 0.099 & & 0.099 & & 0.117 & \\
\hline
\end{tabular}

Note: Standard error in parentheses and $N$ in square brackets. All models significant at $p<.001$.

${ }^{*} p<.05$.

${ }^{* *} p<.01$.

${ }^{* * *} p<.001$. 
Table 5. Multiple linear regression results for the social distance scale; Eastern European, Muslim, and Other ethnic group (fully adjusted model).

\begin{tabular}{|c|c|c|c|c|c|c|c|c|}
\hline \multirow[b]{2}{*}{ Block } & \multirow[b]{2}{*}{ Variable } & \multirow[b]{2}{*}{ Ref } & \multicolumn{2}{|c|}{ Eastern European } & \multicolumn{2}{|c|}{ Muslim } & \multicolumn{2}{|c|}{ Other } \\
\hline & & & $B$ & Beta & $B$ & Beta & $B$ & Beta \\
\hline \multirow[t]{2}{*}{ Demographic } & Gender & Male & $0.008(.145)$ & 0.002 & $-0.073(.153)$ & -0.016 & $-0.031(.125)$ & -0.008 \\
\hline & Age & & $-0.000(.004)$ & -0.003 & $-0.017(.005)^{\star *}$ & -0.129 & $-0.001 .004)$ & -0.010 \\
\hline \multirow[t]{4}{*}{ Social contact } & Daily & Never & $1.166(.259)^{* * *}$ & 0.217 & $1.416(.501)^{* *}$ & 0.092 & $1.153(.278)^{\star * *}$ & 0.180 \\
\hline & $1-2$ times a week & Never & $0.743(.246)^{* *}$ & 0.152 & $1.049(.339)^{\star *}$ & 0.102 & $0.892(.23)^{\star \star \star}$ & 0.201 \\
\hline & $1-2$ times a month & Never & $0.265(.245)$ & 0.054 & $0.963(.329)^{\star *}$ & 0.096 & $0.406(.222)$ & 0.094 \\
\hline & Very rarely & Never & $0.651(.228)^{\star \star}$ & 0.146 & $0.866(.166)^{\star \star \star}$ & 0.177 & $0.629(.213)^{\star *}$ & 0.151 \\
\hline \multirow[t]{2}{*}{ Sectarianism } & Religion Catholic & Protestant & $0.68(.134)^{\star \star *}$ & 0.169 & $0.912(.152)^{\star \star \star}$ & 0.195 & $0.598(.125)^{\star \star \star}$ & 0.158 \\
\hline & Mixed Marriages supports & Opposed & $0.416(.152)^{\star *}$ & 0.090 & $0.703(.171)^{\star \star \star}$ & 0.132 & $0.364(.141)^{*}$ & 0.084 \\
\hline \multirow[t]{6}{*}{ Economic self-interest } & Social Class 1 & Long term unemployed & $0.831(.141)^{\star *}$ & 0.186 & $0.376(.326)$ & 0.072 & $0.897(.265)^{\star *}$ & 0.214 \\
\hline & Social Class 2 & Long term unemployed & $0.935(.286)^{* *}$ & 0.199 & $0.444(.314)$ & 0.081 & $0.965(.256)^{\star \star *}$ & 0.218 \\
\hline & Social Class 3 & Long term unemployed & $1.009(.276)^{\star \star *}$ & 0.245 & $0.186(.292)$ & 0.039 & $1.022(.237)^{\star * *}$ & 0.264 \\
\hline & Degree or higher & No Qualifications & $1.142(.256)^{\star \star \star}$ & 0.261 & $0.891(.267)^{\star *}$ & 0.174 & $1.088(.221)^{\star \star *}$ & 0.264 \\
\hline & GCSE/A Level & No Qualifications & $0.628(.239)^{\star \star}$ & 0.156 & $0.489(.207)^{*}$ & 0.104 & $0.524(.172)^{* *}$ & 0.138 \\
\hline & Household income & Fallen behind prices & $-0.343(.186)^{*}$ & -0.081 & $-0.141(.158)$ & -0.028 & $-0.142(.13)$ & -0.035 \\
\hline \multicolumn{3}{|l|}{$\begin{array}{l}\text { constant } \\
\text { Adjusted } r^{2}\end{array}$} & \multicolumn{2}{|c|}{$\begin{array}{l}0 .<<0 \\
0.158\end{array}$} & \multicolumn{2}{|c|}{$\begin{array}{l}0.455 \\
0.207\end{array}$} & \multicolumn{2}{|c|}{ 0.voc } \\
\hline N & & & \multicolumn{2}{|c|}{830} & \multicolumn{2}{|l|}{813} & \multicolumn{2}{|c|}{$\begin{array}{l}0.161 \\
840\end{array}$} \\
\hline$F$ & & & \multicolumn{2}{|c|}{$p<.0001$} & \multicolumn{2}{|c|}{$p<0.0001$} & \multicolumn{2}{|c|}{$p<.0001$} \\
\hline
\end{tabular}

Note: Standard error in parentheses and $N$ in square brackets.

${ }^{*} p<.05$.

${ }^{* *} p<.01$.

${ }^{\star * *} p<.001$. 


\section{Results}

\section{Eastern Europeans}

More frequent social contact is significantly associated with greater acceptance, with those having the most social contact almost two points higher on the Social Distance Scale (Table 4), and a generally progressive increase as contact increases. Although somewhat attenuated, the association remains significant in the fully adjusted model (Table 5). However, while a stratified analysis (Table 6) shows that this association is similar among the two highest and lowest social classes, it is only seen among Protestants who, overall, are much less accepting of Eastern Europeans. Further analyses (data not shown) show that, even in the top two social classes, Catholics with daily contact with Eastern Europeans are more accepting of them than Protestants, with a difference of almost half a point on the Social Distance Scale. Thus, the data support the social contact theory among Protestants but not Catholics.

Turning to sectarianism as racism, those who favour mixed marriages are more accepting of Eastern Europeans but the coefficient is about half that seen with social contact. The association remains significant in the fully adjusted model. In a stratified analysis (data not shown) the association is similar among Protestants and Catholics ( $B=0.445$ and 0.570 , respectively), although the constant (i.e. the underlying level of acceptance) was lower among Protestants at 5.570 compared to 6.039. Economic self-interest is also associated with acceptance. Having either GCSE/A-level qualifications or a degree is significantly associated with greater acceptance than having no qualifications. It is important to note that those with no qualifications are not a trivial proportion of the population; in this sample they comprise $22 \%$ of all respondents, although with most among the over 55 s (77\%).

Table 6. Multiple linear regression results for social contact and the social distance scale; Eastern European group, divided by social class and religion (all models adjusted for age and gender).

\begin{tabular}{|c|c|c|c|c|c|c|}
\hline \multirow[b]{2}{*}{ Block } & \multirow[b]{2}{*}{ Variable } & & \multicolumn{4}{|c|}{ Reference } \\
\hline & & & B & Beta & $B$ & Beta \\
\hline & Never & & $\begin{array}{l}\text { Social Class } 1 \& 2 \\
{[52]}\end{array}$ & & $\begin{array}{l}\text { Social Class } 3 \text { \& } 4 \\
\text { [91] }\end{array}$ & \\
\hline \multirow[t]{4}{*}{ Social contact } & Very rarely & Never & $\begin{array}{c}1.464(.403)^{\star \star \star} \\
{[133]}\end{array}$ & 0.314 & $\begin{array}{c}0.492(.331) \\
{[178]}\end{array}$ & 0.107 \\
\hline & $1-2$ times a month & Never & $\begin{array}{c}1.184(.415)^{\star *} \\
{[138]}\end{array}$ & 0.263 & $\begin{array}{c}0.399(.385) \\
{[97]}\end{array}$ & 0.071 \\
\hline & 1-2 times a week & Never & $\begin{array}{c}1.499(.407)^{\star * \star} \\
{[145]}\end{array}$ & 0.335 & $\begin{array}{c}0.845(.368)^{*} \\
{[100]}\end{array}$ & 0.157 \\
\hline & Daily & Never & $\begin{array}{c}1.964(.397)^{\star \star *} \\
{[108]}\end{array}$ & 0.416 & $\begin{array}{c}1.434(.365)^{\star * \star} \\
{[67]}\end{array}$ & 0.241 \\
\hline Constant & & & 4.891 & & 4.901 & \\
\hline Adjusted $r^{2}$ & & & 0.080 & & 0.063 & \\
\hline \multirow[t]{2}{*}{$N$} & Never & & $\begin{array}{l}576 \\
\text { Protestant } \\
{[82]}\end{array}$ & & $\begin{array}{l}533 \\
\text { Catholic } \\
{[43]}\end{array}$ & \\
\hline & Very rarely & Never & $\begin{array}{c}1.091(.346)^{\star *} \\
{[139]}\end{array}$ & 0.224 & $\begin{array}{c}0.285(.361) \\
{[128]}\end{array}$ & 0.072 \\
\hline \multirow[t]{3}{*}{ Social contact } & $1-2$ times a month & Never & $\begin{array}{c}1.343(.371)^{* * *} \\
{[97]}\end{array}$ & 0.245 & $\begin{array}{c}-0.240(.410) \\
{[98]}\end{array}$ & -0.056 \\
\hline & 1-2 times a week & Never & $\begin{array}{c}1.77(.367)^{\star * *} \\
{[89]}\end{array}$ & 0.322 & $\begin{array}{c}0.499(.391) \\
{[105]}\end{array}$ & 0.012 \\
\hline & Daily & Never & $\begin{array}{c}2.318(.356)^{\star \star \star} \\
{[70]}\end{array}$ & 0.403 & $\begin{array}{c}0.522(.386) \\
{[74]}\end{array}$ & 0.115 \\
\hline Constant & & & $3.899^{\circ}$ & & $6.419^{\circ}$ & \\
\hline Adjusted $r^{2}$ & & & 0.117 & & 0.044 & \\
\hline N & & & 448 & & 448 & \\
\hline
\end{tabular}

Note: Standard error in parentheses and reference categories in italics. All models significant at $p<.001$. ${ }^{*} p<.05 .{ }^{\star *} p<.01 .{ }^{* * *} p<.001$. 
However, as age is controlled for in the regression, having no qualifications is independently associated with prejudice. Social class is also significantly associated with prejudice, although in the opposite direction to what might be expected; those in the highest social class, higher managerial, administrative, and professional occupations, report higher levels of prejudice against Eastern Europeans than those in lower routine and manual occupations. However, being long-term unemployed or having never worked is associated with less acceptance than is seen with any of the other three social class variables. Perhaps surprisingly, those that feel their income has kept up with or exceeded prices in the last year are more prejudiced against Eastern Europeans than those who feel their household income has fallen behind prices.

In the fully adjusted model, there is support for all three theories (subject to the caveat about social contact and religion noted above), but with social contact and economic self-interest more important than sectarianism.

\section{Muslims}

The second model in Tables 4 and 5 shows those variables that predict levels of prejudice against Muslims, again as measured by the Social Distance Scale. In the fully adjusted model (and in each of the models entering each block separately) gender is not significant, in contrast to attitudes towards Eastern Europeans, but age is. Additionally, Table 5 shows that age has a somewhat stronger association with prejudice than with the other groups, with older people more likely to be prejudiced against Muslims. In this case, the results need to be interpreted with some care as over half of the sample has no contact at all with Muslims. Once again, there is a significant association with social contact but when the model only includes the age and gender adjusted social contact block, there is no obvious gradient. This would suggest that having any contact at all increases the level of acceptance, with little gain after that. However, in the fully adjusted model, there is more evidence of a gradient. Once again, a stratified analysis by social class and religion was undertaken (Table 7). The patterns were consistent in the highest and lowest social class categories, as was seen with the Eastern Europeans, but in contrast more frequent contact was associated with greater acceptance by both Catholics as well as Protestants.

Turning to the variables associated with sectarianism, there was again a significant association with supporting mixed marriages, and the coefficient was larger than with Eastern Europeans. Once again, Catholics were more accepting. These associations remained in the fully adjusted model. Turning to economic self-interest, significant associations with the variables were again seen, although the coefficients tended to be smaller than with Eastern Europeans. However, most of the associations were attenuated to below statistical significance in the fully adjusted model.

\section{'Other' ethnic group}

The final model in Tables 4 and 5 report the results for respondents' prejudice against 'other ethnic groups for example Chinese or Asian'. Once again there is support for the social contact hypothesis, although again the coefficients are somewhat smaller than with Eastern Europeans. A stratified analysis (not shown) is rather similar to that seen with Eastern Europeans. Thus, among Catholics, compared with no contact, those with contact rarely, one to two times per month or daily are not significantly more accepting, although those with contact one to two times per week are $(p=.027)$. 


\section{Discussion}

The starting point of this study was the evidence, primarily from the media and nongovernmental organisations, of growing numbers of racially motivated attacks on ethnic minorities, coupled with the limited amount of existing research on individual determinants of prejudice in Northern Ireland. This paper draws on earlier work but updates it to take account of a very different demographic and political situation, using a new, extended and larger data set, looking at three different groups of minorities and employing the widely used Social Distance Scale.

Three hypotheses were proposed and the findings provide some support for all three. However, before reviewing the theories, itisimportant to note that, in thefullyadjusted model, age only has an impact on attitudes towards Muslims, with older people significantly more likely to reject a Muslim person at a closer social distance to them. The finding that that this does not hold for the two other groups, alongside other results that differ for the three groups provides empirical support for the argument that determinants of prejudice against various ethnic groups are likely to be different.

Support for the social contact hypothesis is only partial. Although, overall, those with more contact with each of the three groups are more accepting of them, this does not apply to Catholics coming into contact with Eastern Europeans or the Other group, a finding that seems to reflect the relatively high level of acceptance of these groups even among Catholics who have little or no contact with them. The findings are encouraging for each of these groups, but especially so for Eastern Europeans, of whom there are over 35,000 in Northern Ireland. The opportunities for contact with Muslims are, however, much less as they number approximately two in every thousand of the total population, substantially limiting their opportunities for contact. This is reflected in the high number of respondents reporting no contact at all.

The findings also offer partial support for the sectarianism hypothesis, with those most accepting of mixed marriages more willing to accept all three groups, although the effect was largest with Muslims and, in general, the coefficients were somewhat smaller than with social contact or economic self-interest. This indicates the need for future research on community relations to include, at the very least, a discussion of racism alongside sectarianism. These findings are consistent with those of Pehrson, Gheorghiu, and Ireland (2012), who found that Protestants were more prejudiced than Catholics but also in their finding that that the greatest difference between them is in relation to attitudes towards Muslims (noting that the coefficient for religion in the fully adjusted model here was almost one). This may seem surprising as one might expect the difference to be greater for Eastern Europeans, the majority of whom that come to Northern Ireland (as measured in migration statistics) are from Catholic countries. Thus, for Catholics, Eastern Europeans are not completely an out-group and they are likely to have contact with them at church, although in some parts of Northern Ireland where these communities are highly concentrated separate masses are now being celebrated in Polish and a selection of other Eastern Europeans languages (McDermott 2011, 233). However, what is less publicised but very important in Northern Ireland is the way that Protestants and Catholics have aligned themselves in relation to the Israeli Palestinian conflict (Anderman 2012; McBride 2013). Protestants have taken to supporting the Israeli cause and Catholics the Palestinian one, with the latter perceiving another community discriminated against by a dominant power. Both sides prominently display this sentiment by flying flags and painting wall murals, predominantly in Belfast. While it may seem surprising to an outsider, the identification with the conflict is an important part of some people's Catholic and Protestant identity. This could be an explanation for the gulf in the attitudes towards Muslims between Catholics and Protestants. 
Table 7. Multiple linear regression results for social contact and the social distance scale; Muslim group, divided by social class and religion (all models adjusted for age and gender).

\begin{tabular}{|c|c|c|c|c|c|c|}
\hline \multirow[b]{2}{*}{ Block } & \multirow[b]{2}{*}{ Variable } & & \multicolumn{3}{|c|}{ Reference } & \multirow[b]{2}{*}{ Beta } \\
\hline & & & B & Beta & B & \\
\hline & Never & & $\begin{array}{l}\text { Social Class } 1 \& 2 \\
\text { [242] }\end{array}$ & & $\begin{array}{l}\text { Social Class } 3 \text { \& } 4 \\
\text { [318] }\end{array}$ & \\
\hline \multirow[t]{4}{*}{ Social contact } & Very rarely & Never & $\begin{array}{c}1.119(.228)^{\star \star \star} \\
{[216]}\end{array}$ & 0.241 & $\begin{array}{c}1.239(.250)^{\star \star \star} \\
{[156]}\end{array}$ & 0.238 \\
\hline & $1-2$ times a month & Never & $\begin{array}{c}1.597(.289)^{\star \star *} \\
{[47]}\end{array}$ & 0.198 & $\begin{array}{c}1.264(.540)^{\star} \\
{[25]}\end{array}$ & 0.109 \\
\hline & 1-2 times a week & Never & $\begin{array}{c}1.007(.380)^{* *} \\
{[38]}\end{array}$ & 0.114 & $\begin{array}{c}2.057(.396)^{* * *} \\
{[21]}\end{array}$ & 0.185 \\
\hline & Daily & Never & $\begin{array}{c}1.552(.367)^{* * *} \\
{[20]}\end{array}$ & 0.129 & $\begin{array}{c}0.828(.834) \\
{[10]}\end{array}$ & 0.055 \\
\hline Constant & & & 5.872 & & 4.631 & \\
\hline Adjusted $r^{2}$ & & & 0.141 & & 0.141 & \\
\hline \multirow[t]{3}{*}{$N$} & & & 563 & & 530 & \\
\hline & Never & & $\begin{array}{l}\text { Protestant } \\
{[255]}\end{array}$ & & $\begin{array}{l}\text { Catholic } \\
\text { [228] }\end{array}$ & \\
\hline & Very rarely & Never & $\begin{array}{c}1.433(.247)^{\star \star \star} \\
{[157]}\end{array}$ & 0.286 & $\begin{array}{c}0.876(.251)^{\star *} \\
{[142]}\end{array}$ & 0.193 \\
\hline \multirow[t]{3}{*}{ Social contact } & $1-2$ times a month & Never & $\begin{array}{c}1.619(.451)^{\star * \star} \\
{[25]}\end{array}$ & 0.156 & $\begin{array}{c}1.230(.335)^{\star * *} \\
{[27]}\end{array}$ & 0.129 \\
\hline & $1-2$ times a week & Never & $\begin{array}{c}1.592(.510)^{\star *} \\
{[27]}\end{array}$ & 0.161 & $\begin{array}{c}1.077(.380)^{\star *} \\
{[22]}\end{array}$ & 0.113 \\
\hline & Daily & Never & $\begin{array}{c}1.912(.644)^{\star \star} \\
{[12]}\end{array}$ & 0.135 & $\begin{array}{c}1.819(.268)^{\star * *} \\
{[11]}\end{array}$ & 0.140 \\
\hline Constant & & & 4.277 & & 61.39 & \\
\hline Adjusted $r^{2}$ & & & 0.142 & & 0.139 & \\
\hline$N$ & & & 476 & & 430 & \\
\hline
\end{tabular}

Note: Standard error in parentheses and reference categories in italics. All models significant at $p<.001$.

${ }^{*} p<.05$.

${ }^{* *} p<.01$.

${ }^{* * *} p<.001$.

The results in relation to economic self-interest reveal that economic determinants have little effect on prejudice against Muslims, which in the model is mainly driven by age, religion, and low levels of contact. This difference may reflect how few Muslims who have migrated to Northern Ireland compete for low-skilled jobs. As The Economist noted 'Many of the 4,000 or so Muslims who live permanently in Ulster are doctors, academics, entrepreneurs and property developers. Only in the past few years have they been joined by a poorer group of asylum-seekers from Somalia' ('On the Other Foot', 2014, 1). With Eastern Europeans, those in a more precarious position are less accepting. Education to degree level or higher is significantly associated with greater acceptance of all ethnic groups, although less so in relation to Muslims.

The most important finding from this analysis is, however, that while there are a number of similarities, there are also some important differences in the strength of the explanatory factors for the three different minority groups. The need for a nuanced approach to race relations applies more generally to the UK, given the diversity of ethnic minority groups in many places, but it is especially important in Northern Ireland because of its unique experience with migration, with two relatively distinct stages. Members of the 'other' ethnic minority groups are more likely to be accepted at all levels of social distance than Eastern Europeans. This could be because of the ambiguity of the ethnic minority in question or because this group is seen as constituting primarily Chinese and 
South Asians, who comprise the majority of long-term migrants in Northern Ireland.

These findings have potential implications for the Stormont government. First, within a framework of anti-discrimination policies, the experiences of each minority group should be considered separately. Second, policies should also address specifically the greater levels of prejudice in the Protestant community. Third, there may be benefits from community initiatives that bring people together with the aim of initiating contact and breaking down barriers between the different communities, although subject to empirical evaluation. Finally, there are implications for the NILT survey. While it is important to ensure continuity between waves, there is an argument that the three categories of ethnic group needs further refinement. In particular, there may be confusion between the Muslim group and the Other, which consists of Asians, some of whom are also Muslim. In addition, while respecting the need for confidentiality, the survey could usefully add geocoded variables, even if only to the level of local government area, as census data show differences in where people born outside of the UK and Northern Ireland are settling. Geocoding would enable linkage with other routine data, facilitating multilevel analysis. However, this does not detract from the excellent work by ARK in conducting the survey and providing the data in such good condition for the use of researchers and others.

Finally, having tested three distinct theories taken from the existing literature it is clear that there is still considerable unexplained variation in attitudes. This calls for further research, especially if improved survey data are to be collected. With rising numbers of ethnic minorities, whether arriving in Northern Ireland or being born in the region, future research will be needed to track changing perceptions of ethnic groups, both to place this issue higher on the policy agenda and to track progress over time, just as has been done with sectarianism.

\section{Acknowledgements}

I am grateful to Dr Adrianna Murphy for methodological advice and support. I am grateful to Dr James Laurence at CMIST, University of Manchester, who supervised my MSc dissertation on which this paper is based. I am also grateful to Dr Rob Ford and Dr Maria Sobolewska, Department of Politics, University of Manchester, for their encouragement as my current Ph.D. supervisors.

\section{Supplemental data}

Supplemental data for this article can be accessed at
http://dx.doi.org/10.1080/1369183X.2015.1081055.

1. The 2011 Northern Ireland Statistics and Research Agency Census figures on reported religion and religion brought up in http://www.nisra.gov.uk/census/key_press_release_2011.pdf.

2. The Census reports only 84 individuals born in Eastern Europe as Muslim $(0.25 \%)$. While the categories in the survey are not mutually exclusive in practice this is very unlikely to be a problem.

3. Mann-Whitney $U$-test

$p=.002 .4 . p=.121$.

5. $p=.785$.

6. $1.97 \%$ of the usually resident population. www.nisra.gov.uk/archive/census/2011/results/keystatistics/summary- report.pdf.

7. This data can be accessed at www.nisra.gov.uk/census/2011_results.html.

8. Social Class was condensed into the 3 class schema rather than 5 because of the small $n$ of respondents. Lower supervisory and technical occupations included only 67 respondents, while higher managerial, administrative, and professional occupations included 318. 


\section{References}

Allport, Gordon W. 1954. The Nature of Prejudice. Garden City, NY: Doubleday-Anchor.

Anderman, Nirit. 2012. "How the Irish View the Israel-Palestinian Conflict." Accessed October 5, 2014. www.haaretz. com/weekend/week-s-end/how-the-irish-view-the-israel-palestinian-conflict.premium1.471003 .

ARK. 2010. “Technical Notes Northern Ireland Life and Times Survey 2010.” Belfast.

Augoustinos, Martha, and Katherine J. Reynolds. 2001. "Prejudice, Racism and Social Psychology." In Understanding Prejudice, Racism, and Social Conflict, edited by Martha Augoustinos and Katherine J. Reynolds, 1-23. London: SAGE.

BBC News. 2013. "Ryan Newberry and David Wilton Jailed for Racist Attack." Accessed October 17, 2014. www.bbc. co.uk/news/uk-northern-ireland-22843823.

Blalock, Hubert M. 1967. Toward a Theory of Minority-Group Relations. New York: Capricorn Books. Blumer, Herbert. 1958. "Prejudice as a Sense of Group Position." Pacific Sociological Review 1 (1): 3-7.

Bobo, Lawrence. 1983. “Whites' Opposition to Busing: Symbolic Racism or Realistic Group Conflict?” Journal of Personality and Social Psychology 45 (6): 1196-1210.

Bonacich,Edna. 1972. “A Theory of Ethnic Antagonism: The Split Labor Market.” American Sociological Review 37(5): 547-559.

Brewer, John D. 1992. "Sectarianism and Racism, and Their Parallels and Differences." Ethnic and Racial Studies 15 (3): 352-364.

Brooks, Dennis. 1975. Race and Labour in London Transport. London: Oxford University Press.

Carvacho, Héctor, Andreas Zick, Andrés Haye, Roberto González, Jorge Manzi, Caroline Kocik, and Melanie Bertl. 2013. "On the Relation Between Social Class and Prejudice: The Roles of Education, Income, and Ideological Attitudes." European Journal of Social Psychology 43 (4): 272-285. doi:10.1002/ejsp.1961.

Case, Charles, Andrew Greely, and Stephen Fuchs. 1989. "Social Determinants of Racial Prejudice." Sociological Perspectives 32: 469-483.

Citrin, Jack, Donald P. Green, Christopher Muste, and Cara Wong. 1997. "Public Opinion Toward Immigration Reform: The Role of Economic Motivations." The Journal of Politics 59 (03): 858-881.

Connolly, Paul, and Michaela Keenan. 2000. Racial Attitudes and Prejudice in Northern Ireland. Belfast: Northern Ireland Statistics and Research Agency.

Cox, Michael, Adrian Guelke, and Fiona Stephen. 2000. A Farewell to Arms? From "Long War" to Long Peace in Northern Ireland. Manchester: Manchester University Press.

Dixon, Jeffrey C., and Michael S. Rosenbaum. 2004. "Nice to Know You? Testing Contact, Cultural, and Group Threat Theories of Anti-Black and Anti-Hispanic Stereotypes." Social Science Quarterly 85 (2): $257-280$.

Dovido, John F., Miles Hewstone, Peter Glick, and Victoria M. Esses, eds. 2010. The SAGE Handbook of 
Prejudice, Stereotyping and Discrimination. London: SAGE.

Finlay, Andrew. 2010. Governing Ethnic Conflict: Consociation, Identity and the Price of Peace. New York: Routledge.

Ford, Robert, and Matthew J. Goodwin. 2010. "Angry White Men: Individual and Contextual Predictors of Support for the British National Party." Political Studies 58 (1): 1-25.

Gallagher, Eamonn. 2007. "Racism and Citizenship Education in Northern Ireland." Irish Educational Studies 26 (3): 253-269.

Gilligan, Chris. 2008. "The Place of Northern Ireland in Ethnic and Racial Studies in Britain: What Place?" C-SAP

'Race-ing Forward', 1-10. University of Northampton.

Golder, Matt. 2003. "Electoral Institutions, Unemployment and Extreme Right Parties: A Correction." British Journal of Political Science 33 (3): 525-534.

Goldthorpe, John H., Catriona Llewellyn, and Clive Payne. 1987. Social Mobility and Class Structure in Modern Britain. Oxford: Clarendon Press.

Hagendoorn, Louk, and Shervin Nekuee. 1999. Education and Racism: A Cross-National Inventory of Positive Effects of Education on Ethnic Tolerance. Aldershot, UK: Ashgate.

Hainsworth, Paul. 1998. Divided Society: Ethnic Minorities and Racism in Northern Ireland. London: Pluto Press. Hayes, Bernadette C., and Lizanne Dowds. 2006. "Social Contact, Cultural Marginality or Economic Self-interest?

Attitudes Towards Immigrants in Northern Ireland." Journal of Ethnic and Migration Studies 32 (3): 455476. Hewstone, Miles, Ed Cairns, Alberto Voci, Juergen Hamberger, and Ulrike Niens. 2006. "Intergroup Contact, Forgiveness, and Experience of "The Troubles" in Northern Ireland." Journal of Social Issues 62 (1): 99-120.

Jarman, Neil, and Rachel Monaghan. 2003. "Racist Harassment in Northern Ireland.” In Belfast: Office of First Minister and Deputy First Minister.

Katz, Daniel, and Kenneth Braly. 1933. "Racial stereotypes of one Hundred College Students." The Journal of Abnormal and Social Psychology 28 (3): 280-290.

Kluegel, James R., and Eliot R. Smith. 1983. “Affirmative Action Attitudes: Effects of Self-interest, Racial Affect, and Stratification Beliefs on Whites' Views.” Social Forces 61 (3): 797-824.

Knox, Colin. 2010. "Tackling Racism in Northern Ireland: “The Race Hate Capital of Europe."' Journal Social Policy 40 (2): 387-412.

Mayda, Anna Maria. 2006. "Who Is Against Immigration? A Cross-country Investigation of Individual Attitudes Toward Immigrants." The Review of Economics and Statistics 88 (3): 510-530.

McBride, Sam. 2013. “Ambassador 'Torn over Israel Flags in NI.” The News Letter.

McCaffery, Steven. 2013. "Racism, the Good Friday Agreement and Northern Ireland's New Minority." 
Accessed July 20, 2013. www.thedetail.tv/issues/189/racism-and-the-good-friday-agreement/racismthe-good-friday-agreement- and-northern-ireland's-'new-minority'.

McDermott, Philip. 2011. Migrant Languages in the Public Space: A Case Study from Northern Ireland. Berlin: Lit. McDonald, Henry. 2009. "Romanians Leave Belfast after Racist Attacks." The Guardian, London.

McVeigh, Robbie. 1992. "The Specificity of Irish Racism." Race \& Class 33 (4): 31-45.

McVeigh, Robbie. 1998a. "Is Sectarianism Racism? Theorising the Racism/Sectarianism Interface." In Rethinking Northern Ireland, edited by David Miller, 179-198. London: Longman.

McVeigh, Robbie. 1998b. “There's No Racism Here Because There's No Black People Here." In Divided Society: Ethnic Minorities and Racism in Northern Ireland, edited by Paul Hainsworth, 11-32. London: Pluto.

McVeigh, Robbie, and Bill Rolston. 2007. "From Good Friday to Good Relations: Sectarianism, Racism and the Northern Ireland state." Race \& Class 48 (4): 1-23.

Nic Craith, Mairead. 2002. Plural Identities, Singular Narratives: The Case of Northern Ireland. New York: Oxford: Berghahn Books.

NICEM (Northern Ireland Council for Ethnic Minorities). 2013. "Race and Criminal Justice in Northern Ireland Towards a Blueprint for the Eradication of Racism." CJSNI. http://www.nicem.org.uk/uploads/publications/Race_and_Criminal_Justice_2013.pdf.

"On the Other Foot: They Do Things Differently in Northern Ireland-Including Muslim-Bashing." 2014. The Economist. http://www.economist.com/news/britain/21604192-they-do-things-differently-northernirelandincluding-muslim- bashing-other-foot.

van Oorschot, Wim. 2000. "Who Should Get What, and Why? On Deservingness Criteria and the Conditionality of Solidarity among the Public." Policy \& Politics 28 (1): 33-48.

van Oorschot, Wim, and Wilfred Uunk. 2007. "Welfare Spending and the Public's Concern for Immigrants: Multilevel Evidence for Eighteen European Countries." Comparative Politics 40 (1): 63-82. doi:10.2307/20434064.

O’Rourke, Kevin H., and Richard Sinnott. 2006. “The Determinants of Individual Attitudes Towards Immigration."

European Journal of Political Economy 22 (4): 838-861.

Paolini, Stefania, Miles Hewstone, Ed Cairns, and Alberto Voci. 2004. "Effects of Direct and Indirect Cross-group Friendships on Judgments of Catholics and Protestants in Northern Ireland: The Mediating Role of an Anxiety- Reduction Mechanism." Personality and Social Psychology Bulletin 30 (6): 770786.

Pehrson, Samuel, Mirona A. Gheorghiu, and Thomas Ireland. 2012. "Cultural Threat and Anti-immigrant Prejudice: The Case of Protestants in Northern Ireland." Journal of Community and Applied Social Psychology 22 (2): 111-124.

Pettigrew, Thomas F. 1998. "Intergroup Contact Theory." Annual Review of Psychology 49 (1): 65-85.

Pettigrew, Thomas F., and Linda R. Tropp. 2006. “A Meta-analytic Test of Intergroup Contact Theory.” 
Journal of Personality and Social Psychology 90 (5): 751-783.

Police Service of Northern Ireland. 2014. "Incidents and Crimes with a Hate Motivation Recorded by the Police in Northern Ireland: Quarterly Update to 30 June 2014." Quarterly Hate Motivations Bulletin.

Quillian, Lincoln. 1995. "Prejudice as a Response to Perceived Group Threat: Population Composition and Anti- immigrant and Racial Prejudice in Europe." American Sociological Review 60 (4): 586-611.

Raijman, Rebeca, Moshe Semyonov, and Peter Schmidt. 2003. "Do Foreigners Deserve Rights? Determinants of Public Views Towards Foreigners in Germany and Israel." European Sociological Review 19 (4): 379-392.

Russell, Raymond. 2012. Migration in Northern Ireland: An Update. A Research and Information Service Research Paper. Belfast: Northern Ireland Assembly.

Scheepers, Peer, Mérove Gijsberts, and Marcel Coenders. 2002. "Ethnic Exclusionism in European Countries. Public Opposition to Civil Rights for Legal Migrants as a Response to Perceived Ethnic Threat." European Sociological Review 18 (1): 17-34.

Scheve, Kenneth F., and Matthew J. Slaughter. 2001. "Labor Market Competition and Individual Preferences over Immigration Policy." Review of Economics and Statistics 83 (1): 133-145.

Schuman, Howard, Charlotte Steeh, and Bobo Lawrence. 1997. Racial Attitudes in American: Trends and Interpretations. Cambridge, MA: Harvard University Press.

Smith, M. L. R. 1996. "The Intellectual Internment of a Conflict: The Forgotten War in Northern Ireland." International Affairs 75 (1): 77-97.

Wagner, Ulrich, and Andreas Zick. 1995. "The Relation of Formal Education to Ethnic Prejudice: Its Reliability, Validity and Explanation." European Journal of Social Psychology 25: 41-56.

Wallace, Alison, Ruth McAreavey, and Karl Atkin. 2013. Poverty and Ethnicity in Northern Ireland: An Evidence Review. York: Joseph Rowntree Foundation. 